\title{
Editorial Editorial
}

\author{
Mario L.lovaldi*
}

Este número de la Revista incluye, entre otros, 5 artículos que tienen como eje la revisión o la resolución de la patología hepática.

Maurette y col. ${ }^{1}$ presentan la primera publicación del abordaje simultáneo del tumor primario y las metástasis hepáticas de cáncer colorrectal por vía laparoscópica. Es una condición que requiere un equipo multidisciplinario entrenado y una selección adecuada de los pacientes para la realización segura de esta intervención, por lo que es difícil reunir grandes series de pacientes. Este artículo es una revisión retrospectiva de 21 pacientes que cumplieron con los criterios de inclusión. Y además cumplen con la premisa de que el cambio de abordaje no debe afectar los resultados posoperatorios ni oncológicos y que el objetivo final debe ser una resección Ro. En las conclusiones, los autores expresan la necesidad de series aleatorizadas controladas para arribar a conclusiones más fuertes; sin embargo, lamentablemente en cirugía de alta complejidad, esto es poco plausible y una expresión de deseo.

Fernández y col. ${ }^{2}$ presentan los resultados de los primeros 8 años del Programa de Trasplante Hepático en Mar del Plata, iniciado en el año 2010. Se describen los detalles de su puesta en marcha y los resultados de esta primera fase. Lo que es interesante es la formación de centros de esta complejidad en el interior del país para descomprimir la necesidad de un área de influencia que tiene una población mayor de un millón de habitantes.

Nari y col. ${ }^{3}$ refieren los resultados de la aplicación del programa ERAS en hepatectomías por laparotomía. EI ERAS (Early Recovery After Surgery) o ERP (Enhanced Recovery Program) -como lo definen los au- tores-es un plan de conductas pautadas para disminuir el tiempo de internación y el estrés del paciente. Requiere una educación detallada de este y de su familia para la adherencia al ingreso del programa y también un compromiso de todos los servicios médicos involucrados. Se trata de una revisión retrospectiva de una base de datos prospectiva que incluye una variedad de intervenciones hepáticas y simultáneas. Los autores concluyen que fue factible lograr la disminución del tiempo de internación con baja tasa de reinternaciones. López Marcano y col. ${ }^{4}$ publican una serie de 19 pacientes de hepatocarcinoma en hígado no cirrótico. Es una revisión retrospectiva de historias clínicas que incluyeron esta condición en ausencia de cirrosis y hepatopatía crónica. Sin embargo, ciertas enfermedades hereditarias como la glucogenosis tipo 1 o el síndrome de Alagille forman parte de las hepatopatías crónicas poco frecuentes. Desafortunadamente no se menciona cuántos carcinomas hepatocelulares pertenecieron a la variante fibrolamelar. La serie es muy interesante y, como consecuencia, nos surge la pregunta de cuáles serían los factores que pueden hacer que la prevalencia en esa zona de México sea superior respecto de otras zonas geográficas.

H. Esteva ${ }^{5}$ hace una revisión centenaria de la técnica de Mabit para la hidatidosis en general y en especial para la hidatidosis hepática, con datos interesantes y por muchos ignorados. Mabit fue jefe de Cirugía del Hospital Francés de Buenos Aires aproximadamente entre 1898 y 1908.

De manera que, sin desmerecer el resto de los artículos, este número es de especial interés para aquellos cirujanos dedicados a la cirugía del hígado.

\section{- ENGLISH VERSION}

This issue of the Revista Argentina de Cirugía includes five articles focused on the review or management of liver disease.

Maurette et al. ${ }^{1}$ present the first publication about the simultaneous approach for the primary tumor and colorectal liver metastases by laparoscopy. As this condition requires a well-trained multidisciplinary team and adequate selection of patients to perform a safe procedure, the probability of gathering large series of patients is not easy. The authors made a retrospective review of 21 patients who fulfilled the inclusion criteria following the premise that the change of approach 
should not affect the postoperative or oncologic results, with a final aim of achieving an $\mathrm{RO}$ resection. Finally, they concluded that randomized controlled series are needed to reach stronger conclusions; unfortunately, this wish is unlikely to happen in the setting of high complexity surgeries.

Fernández et al. ${ }^{2}$ reported the results of the first eight years of experience of the Liver Transplant Program in Mar del Plata, and described the operational details and results of this first phase. The creation of such complex centers in the inland part of the country constitutes an interesting initiative to satisfy the needs of an area of influence with a population with more than 1 million inhabitants.

Nari et al. ${ }^{3}$ presented the results of an enhanced recovery program (ERP) in open liver resections. Enhanced recovery after surgery programs are care pathways designed to reduce hospital length of stay and patients' stress. These programs require thorough education of the patients and their families for adherence to and maintenance of the program, and commitment of all the healthcare providers involved. The paper is a retrospective review of a prospective database which included a variety of liver resections and simultaneous procedures. The authors concluded that the program succeeded in reducing hospital length of stay and readmissions.

López Marcano et al. ${ }^{4}$ reported a series of 19 patients with hepatocellular carcionoma in non-cirrhotic liver. They conducted a retrospective review of the medical records of patients with this condition with absence of history of liver cirrhosis or chronic liver disease. However, certain rare genetic diseases as type 1 glycogen storage disease or Alagille syndrome are also chronic liver diseases. Unfortunately, the authors did not mention how many fibrolamellar hepatocellular carcinomas were included in the study. The series is very interesting and we ask ourselves which factors could have influenced to increase the prevalence in that area of Mexico compared with other geographic zones.

H. Esteva ${ }^{5}$ made a 100 -year review of Mabit's technique for hydatidosis, particularly liver hydatidosis, with interesting and largely ignored data. Mabit was Chief of Surgery at the Hospital Francés of Buenos Aires between 1898 and 1908 .

Therefore, without disregarding the rest of the articles, this issue is of special interest to those surgeons dedicated to liver surgery.
1. RJ Maurette, MD García Ejarque, H Ruíz, ML Bregante, DJ Bogetti y col. Abordaje laparoscópico del cáncer de colon con metástasis hepáticas . Rev Argent Cirug 2019;111(4):245-267

2. DL Fernández, FW García, RA Bracco. Organización y desarrollo de un programa de trasplante hepático. Rev Argent Cirug 2019;111(4):207-226

3. G Nari, J Layun, D Mariot, L Viotto, ME De Elias y col. Resultados de un programa Enhanced Recovery en resecciones hepáticas. Rev Argent Cirug 2019;111(4):227-235

4. A López Marcano, M Serradilla Martin, JM Ramia Ángel, A Palomares Cano, $\mathrm{R}$ De La Plaza Llamas y col. Hepatocarcinoma en hígado no cirrótico. Rev Argent Cirug 2019;111(4):236-244

5. H Esteva. La técnica de Mabit para la hidatidosis. Una revisión centenaria. Rev Argent Cirug 2019;111(4):268-273 